\title{
How Behavioral Factors Influence Investment Performance of Individual Investors in Pakistan Stock Market: A Moderated Mediation Approach
}

\author{
Mumtaz Ahmad ${ }^{a}$, Iqra Mehboob ${ }^{b}$, Syed Zain ul Abdin ${ }^{c}$ \\ ${ }^{a}$ Department of Commerce, The Islamia University of Bahawalpur, Pakistan \\ Email: mumtaz.ahmad@iub.edu.pk \\ ${ }^{\mathrm{b}}$ Department of Commerce, The Islamia University of Bahawalpur, Pakistan \\ Email: iqramehboobo7@gmail.com \\ c IBM \&AS, Department of Finance, The Islamia University of Bahawalpur, Pakistan \\ Email: zain.naqvi@iub.edu.pk
}

\begin{tabular}{ll}
\hline ARTICLE DETAILS & ABSTRACT \\
\hline History: & The primary objective of study is to know the influence of behavioral \\
Accepted 25 August 2021 & factors on investor's investment decision and investment performance. \\
Available Online September 2021 & Four behavioral factors as herding, prospect factors and market factors \\
& are used in this study and financial literacy as a moderating variable \\
& among the behavioral factors and investment decision. We use the \\
Keywords: & questionnaire to collect primary data from individual investors actually \\
Behavioral Finance, Pakistan & trading in Pakistan Stock Exchange. For data analysis, we utilize AMOS \\
Stock Exchange, Investors & software and Hayes Process tool in two stages. The findings reveal that \\
Decisions, Investment & behavioral factors positively influence investment decision and \\
Performance and Financial & investment performance. But there is no moderating role of financial \\
Literacy & literacy. In addition to these, individual investors and security \\
& organizations can ultimately take advantage from the results of this \\
JEL Classification: & research as a guide for their analysis and forecasting of security market \\
P33, F31,G11 & trends in order to maximize the outcome and to improve their \\
& investment efficiency. Further, study recommended investigation of all \\
investor types and in all financial markets including the behaviors of \\
institutional investors along with behavioral financial factors; we should \\
consider some economic factors that could have an impact on investors' \\
decisions.
\end{tabular}

(C) 2021 The authors. Published by SPCRD Global Publishing. This is an open access article under the Creative Commons Attribution-

NonCommercial 4.0

Corresponding author's email address: mumtaz.ahmad@iub.edu.pk

\section{Introduction}

Standard finance assumes, in the investment decision-making process individuals behave rationally and take into account all available information. According to Orthodox economic theories have held that investors in the equity market often act rationally when making investment decisions (Nayak and Kumar, 2020). As noted, efficient market hypothesis principle describes that the price of securities that are traded in the market is right at any given time and represents all available 


\section{Review of Economics and Development Studies, Vol. 7 (3) 2021, 395-405}

information. The efficient market hypothesis notes that the share price represents all the details available (Zahera and Bansal, 2018). According to Peters, (1996) centered on knowledge and rationality the efficient market hypothesis characterized economic theory until the198os. Although, the EMH has enormously struggled to justify behavior of the market probably quite significantly, becoming incapable to understand why US share prices dropped by more than thirty per cent over the two months period preceding the October 1987 crisis.

Traditional finance during the past decade was used to know about how investors create their investment decisions (Keswani et al 2019).However, behavioral economists reject this definition of perfect rationality, claiming that an investor's irrationality can happen as a consequence of incorrect assumptions, various perceptions of scenarios, and perception distortion and influencing their day-today investment decisions based on feelings, purpose, behavior, and social connection (Jhandir \& Elahi, 2014). Investors respond to and perceive the same information in different ways, leading to the transmission of different interpretations of market signals, leading to distinguished conduct.

Currently, behavioral finance has been developed to understand investor behavior when no satisfactory explanations are given by conventional financial theory. In this modern field, studies have not solved the issue of assessing which of the corresponding factors are most crucial while making an investment decision (heuristic, herding, prospect and market) responding to the following research questions which are main target of the current study.

- What are impacts of the behavioral factors (heuristic, herding, prospect and market factors on investment decisions at the Pakistan Stock Exchange among individual investors?

- What are impacts of the behavioral factors (heuristic, herding, prospect and market factors on investment performance at the Pakistan Stock Exchange among individual investors?

- What is the impact of investment decisions on investment performance at the Pakistan Stock Exchange among individual investors?

- Is financial literacy playing a role as a moderator in the relation between behavioral factors and investment decision and performance?

For this study authors got motivation from several aspects as, first previously, many studies have been performed in advanced countries upon the effects of behavioral factors, demographic factors related to investment decision and investment performance. A further significant consideration is that, because of the culture differences, values and financial market infrastructure, financial literacy and level of education, the outcomes of studies done in developed countries cannot be applied to developing countries. It is, however, necessary to know which behavioral factors influence the decision-making of stock exchange investors in Pakistan because Pakistani shareholders tend to obey the actions of their herds and are affected by their close relatives and friends' views.

Further, authors got courage from Areiqat et al (2019) recommendation in which they studied few behavioral factors with investment decision and recommended that these variables are insufficient so we should include other behavioral factors in future studies to make it a comprehensive research work. Similarly, Financial literacy research has grown dramatically for the US and other western countries since the 2000s (Lusardi and Mitchell, 2014), but is still pretty rare in Pakistan. So we investigate the moderating role of financial literacy amongst behavioral factors and investment decision and performance.

By attempting to fill this gap because contributes to the literature of behavioral finance. Pakistan 


\section{Review of Economics and Development Studies, Vol. 7 (3) 2021, 395-405}

is one of the growing developing economies in the world. Market regulators and policy-makers are worried about individual investor behavioral patterns. Areiqat et al (2019) exposed that behavioral indicators helps the investors to choose a successful stock investment strategy..It is known as psychology has effect on the behavior of market players and how individual investors make choices: how they view and acknowledge in particular (Antony 2019).

\section{Theoretical Framework and Hypothesis Development}

The psychologists, Kahneman and Tversky, (1979) they established the basis of the prospect theory are one of the most essential and parenting research carrying out related to the behavioral factor and investment decisions. The prospect theory was implemented as substitute to the expected utility theory, rational expectation theory and the effective market hypothesis. Thaler (1980) has put forward ideas of applying the prospect principle to financial system. Being a finance theorist, he believes that when making investment decisions, people do not always behave logically, they often make mistakes. Recent financial dynamics critically state financial markets have become more competitive and unpredictable (Qureshi et al 2012).

In such circumstances, the predicted utility principle and Efficient Market Hypothesis as stated by the traditional financial theory cannot clarify the image regarding the investor's investment behavior and preferences. According to Baker and Nofsinger, (2010), investment decisions are influenced through "cognitive mistakes", "fundamental heuristics" and "psychological prejudices".

Behavioral finance has become an integral component of making an investment decision as it influence investor's performance (Jahanzeb et al 2012). Many proponent of behavioral finance claim that due to irrational behavior investment show poor performance this exclude investors from the security market. Some others, on the other hand, suggest that over-confident investors with excessive trading behavior might benefit from high results (Anderson et al 2005). Kyle and Wang (1997) describe overconfidence as the behavior of someone who over-evaluates the accuracy of their own data and sees an overconfident investor one who's "subjective distributions of probability are too tight." The overconfident investors deal far greater than other rational challenger in the balanced situation, and anticipate a better investment return in the prolonged run.

Mahmood et al (2016) in an effort to recognize about the influence of behavioral factors like heuristic, prospect and herding on investment performance and revealed that herding and heuristic was positively influence investment performance while prospect is negatively influence investment performance. Similarly, Javed et al. (2017) revealed the results in Pakistani stock market that behavioral factors like herding, some heuristics (over confidence, availability and representativeness) have significant influence in optimistic way on investment performance. Hence, above literature established the facts that behavioral factors may influence investment performance of individual investors. Thus, our first hypothesis is:

H1: Behavioral factors influence investment performance of individual investors.

Investors and financial analysts use a heuristic approach to speeding up analysis and investment decisions (Nayak and Kumar, 2020). According to Perveen et al (2020), there are mental shortcuts that allow fast decisions under uncertainty. In dynamic and unpredictable circumstances, individuals use this criterion to make decisions and relate to the heuristics (Qureshi et al 2012). Overconfidence is a perceptual heuristic tendency that could be defined as unjustified beliefs in one's logical judgment, decisions and perceptual capabilities. Investors have become overconfident in their investment skills, and this will proceed to investment mistakes (Arieqat et al 2019). This implies that when investors 


\section{Review of Economics and Development Studies, Vol. 7 (3) 2021, 395-405}

overestimate their investment capacity, when making their investment choice, they make misjudgment. According Keswani et al (2019) overestimation of the awareness of investors based on their positive business experience.

The mental shortcuts in decision making process that is opposite to the gathering and analysis of the information are known as "heuristic" and these mental shortcuts are helpful in complex and uncertain situations however they may lead to biased decision (Khan et al 2017). Ahmad (2018) in his study discussed the investor behavior and investment decisions. Similarly, Availability bias is a perceptual heuristic bias, also regarded as a mental shortcut, which arises as individuals in their decisions or predictions depend too much on readily accessible information (Ngoc, 2014). According to Abreu (2014), the existence of anchoring means that investors make an evaluation about their own anchor and adapt to an evaluation. When making decisions, the propensity to adhere towards one bit of information is regarded as Anchoring (Kanagasabai and Aggarwal 2020). One of the described phenomenon's is herding, pertaining to which investors appear to disregard their own private views and follow trading behavior of their equivalents (Aharon 2020).

Investors prefer to differently consider every aspect of their investment collection, which may leads to ineffectiveness and uncertainty in investment decision-making (Shiller, 2000).Market-related factors influence can be seen on the actions of investors and this can contribute to a major change in investor decision-making (Keswani et al 2019). Individual investment decision making process even get affected by several psychological factors which are derived from market forces such as price change, market knowledge, historical tendencies of stocks, essentials of given shares, customer priority and over response to price variation (Nayak and kumar 2020).So, our second hypothesis is:

H2: Behavioral factors influence investment decisions of individual investors

As clarified overhead, previous literature have mostly studied the straight influence of behavioral factors of individual investors on investment decisions and investment performance and conveyed the diverse outcomes (Keswani et al., 2019; Nayak and Kumar, 2020). A primary constraint with these researchers work is that they are unsuccessful to explain the intervening role of investment decisions among the relationship of behavioral factors and investment performance. Theoretically, prospect theory for decision making commit that individual's decisions are supported by the possible worth of losses as well as gain than the ultimate result, furthermore individual make assessment of these losses and gains by using sure psychological shortcuts to release the burden of mental activities in decision making (Kahneman \& Tversky, 1979).

Theoretically, later on, Abdin et al., (2017) confirmed the mediating role of investment decisions (in the presence of anomalies)between the heuristics and investment performance in term of hazard and yield because with the help of decision theory individuals are make better decisions (Slovic et al,. 1977)..From the above arguments, this study foresees that investment decision is a missing link among behavioral factors and investment performance. Therefore, our third hypothesis is that:

H3: Investment decision mediates the relation between behavioral factors and investment performance.

There are two main dimensions of financial literacy have been discussed in the literature i.e. perceived and actual. Perceived financial literacy is a self-trust and believes of an individual on their own financial knowledge (Carlson et al 2009). However an individual with higher level of presumed financial knowledge and lower level of real financial knowledge might be considered as overconfident (Allgood and Walstad 2016). 


\section{Review of Economics and Development Studies, Vol. 7 (3) 2021, 395-405}

Financial literacy is valuable and emerged as substantial need for investor's decision-making over the years. It is a specific knowledge unlike the general knowledge of financial products. It is also the capacity for effective wealth management and informed financial decision-making (Ahmad et al 2018). Similarly, Gouws and Shuttle worth (2009) revealed that financial literacy is the basic skill needed for making accurate and informed investment decisions at individual and organizational level.

Financial literacy has become a very interesting matter in recent years, as financial markets have turn into more dynamic and it has become problematic to make knowledgeable choices (Arif, 2015). Finally, on the base of above discussions it is concluded that fourth hypothesis will be as:

H4: Financial literacy moderates the relation between behavioral factors and investment decision.

Figure 1: Conceptual frame of study)

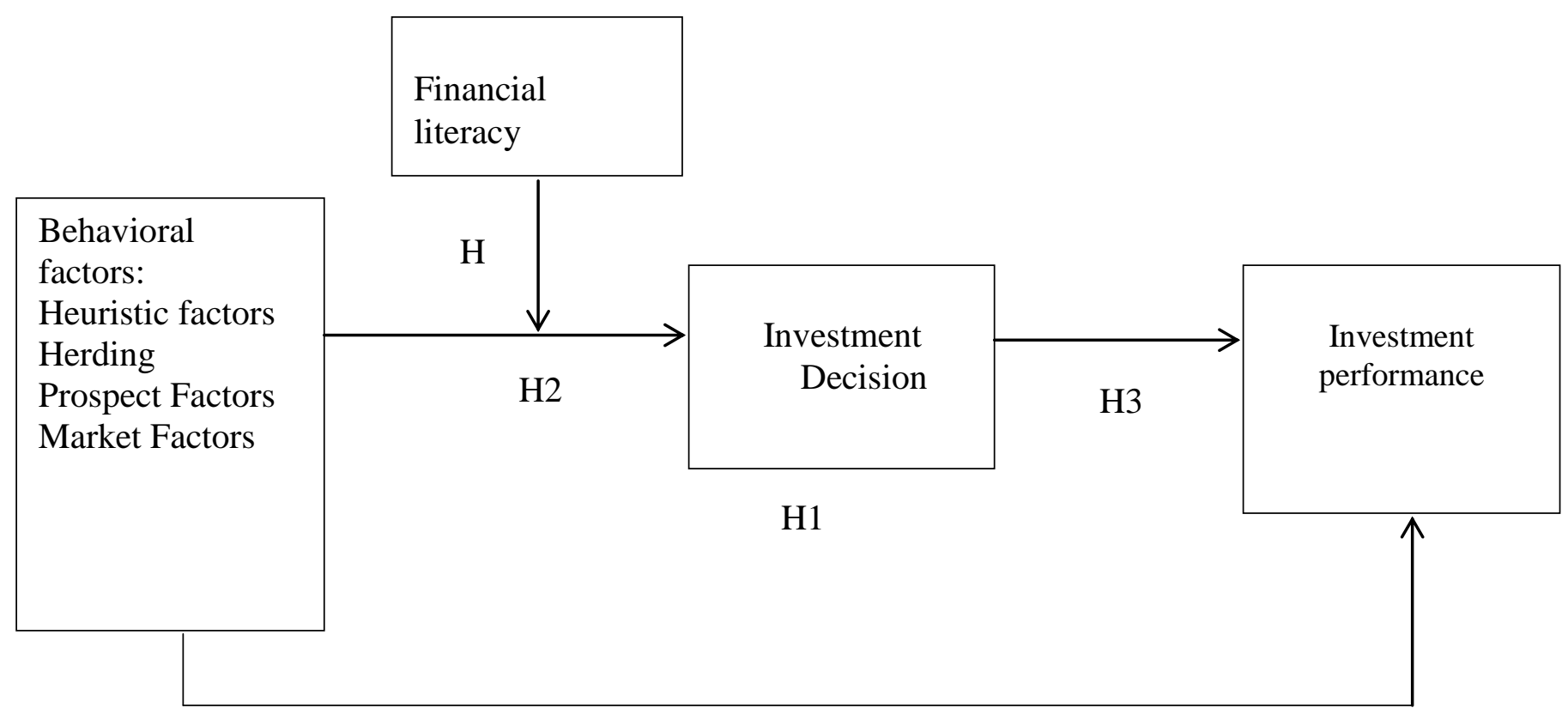

\section{Research Methodology}

\subsection{Data, Sample Size, Sampling Procedure and Measurement of Variables}

The sampling frame is defined by Cooper and Schindler (2003) that set of all the population elements from where the sample is taken. In this active individual investors were selected in Pakistan Stock Exchange. Convenience and purposeful sampling methods are used to achieve the goals of the study. There are two reasons to choose this sampling techniques; first, it is one of the costs and time effective, second, willingness and availability of respondents is compulsory for data collection. We visited brokerage houses to collect the data and total of 500 survey questionnaire distributed among the individual investors in Pakistan Stock Exchange out of which 400 returned and 352 were usable.

All items in the questionnaire were answered using a five-point Likert scale from 1 (strongly disagree) to 5 (strongly agreed) except then specified. To measure heuristics, we used five dimensions of heuristics that are 3 items for overconfidence taken from (Babajide and Adetiloye 2012). Similarly, 2 items used to measure representativeness, 1 item focused on gambler's fallacy, 2 items for anchoring, 4 items for herding, 7 items for prospect factors, 6 items for market factors and 2 items for availability are adopted by (Waweru et al, 2008). For the measurement of investment decision, 7 items are adopted from (Pasewark \& Riley, 2010). Three items were used to measure the investment performance 


\section{Review of Economics and Development Studies, Vol. 7 (3) 2021, 395-405}

taken by (Phuoc and Thu Ha 2011).similarly, 8 items are used to measure financial literacy which were adopted from (Al-Tamimi and Kalli, 2009).

\section{Results and Discussion}

\subsection{Data Screening, Cleaning and Assessment of Outliers}

While completing of the data entry process, while punching data upon receipt of the questionnaires, the researcher reviewed and verified that all questions had been responded. For this, the authors have been visited manually from case to case with great care to search any omitted value in the excel data file and found that out of 400 questionnaires 361 were usable and rest of the 39 questionnaires completely rejected due to lack of completion and omitted values as recommended by (Tabachnick \& Fidell, 2007).

In this study, authors used the recommendation of Hodge and Austin (2004) suggestions and used the Mahalanobis distance statistical approach on the basis of chi-square values at critical alpha 0.001 as a criterion for the identification of outliers in the results. After applying the statistical gauge Mahalanobis distance, author found that 7 extreme values in the data then these values deleted from data set and remaining data set of 352 sample size used for further analysis.

Table 4.1: Correlations

\begin{tabular}{|c|c|c|c|c|c|c|c|c|c|}
\hline & $\begin{array}{l}\text { Gend } \\
\text { er }\end{array}$ & Age & $\begin{array}{l}\text { Educatio } \\
\mathrm{n} \\
\text { Level }\end{array}$ & $\begin{array}{l}\text { Heurist } \\
\text { ic } \\
\text { factors }\end{array}$ & $\begin{array}{l}\text { Herdi } \\
\text { ng }\end{array}$ & $\begin{array}{l}\text { Prospe } \\
\mathrm{ct} \\
\text { factors }\end{array}$ & $\begin{array}{l}\text { Marke } \\
\mathrm{t} \\
\text { factors }\end{array}$ & $\begin{array}{l}\text { Investmen } \\
\text { t decision }\end{array}$ & $\begin{array}{l}\text { Investment } \\
\text { performan } \\
\text { ce }\end{array}$ \\
\hline Gender & 1 & & & & & & & & \\
\hline Age & .015 & 1 & & & & & & & \\
\hline $\begin{array}{l}\text { Education } \\
\text { Level }\end{array}$ & -.013 & $\begin{array}{l}- \\
.080\end{array}$ & 1 & & & & & & \\
\hline $\begin{array}{l}\text { Heuristic } \\
\text { factors }\end{array}$ & -.025 & ${ }_{*} .141^{*}$ & $.108^{*}$ & 1 & & & & & \\
\hline Herding & .002 & $\begin{array}{l}- \\
.035\end{array}$ & .064 & $.180^{* *}$ & 1 & & & & \\
\hline $\begin{array}{l}\text { Prospect } \\
\text { factors }\end{array}$ & .053 & -.017 & .087 & $.438^{* *}$ & $.171^{* *}$ & 1 & & & \\
\hline $\begin{array}{l}\text { Market } \\
\text { factors }\end{array}$ & .058 & .065 & .077 & $\cdot 347^{* *}$ & $.232^{\star *}$ & $.336^{* *}$ & 1 & & \\
\hline $\begin{array}{l}\text { Investmen } \\
\mathrm{t} \text { decision }\end{array}$ & -.043 & .071 & $.140^{* *}$ & $.389^{* *}$ & $.273^{* *}$ & $.323^{* *}$ & $.387^{* *}$ & 1 & \\
\hline $\begin{array}{l}\text { Investmen } \\
\mathrm{t} \\
\text { performa } \\
\text { nce }\end{array}$ & .021 & .015 & $.190^{* *}$ & $.455^{* \star}$ & $.416^{* *}$ & $.411^{\star *}$ & $.500^{* *}$ & $.538^{* *}$ & 1 \\
\hline $\begin{array}{l}\text { Financial } \\
\text { literacy }\end{array}$ & $-.118^{*}$ & $.148^{*}$ & .073 & $.236^{* *}$ & $.154^{* *}$ & $.220^{* *}$ & $.282^{* *}$ & $.677^{* *}$ & $.366^{* *}$ \\
\hline
\end{tabular}

Gender male $=1$, female $=2{ }^{* * *} \mathrm{p}<0.001,{ }^{* *} \mathrm{p}<0.01,{ }^{*} \mathrm{p}<0.05$

According to Hair et al (2010) variance inflated factor (VIF) exceeding 10 and the tolerance value below 0.10 indicate the possible issue of multicollinearity. In this study, authors used both methods (VIF method and correlation) to check the problem of multicollinearity. However, the results show that 
Review of Economics and Development Studies, Vol. 7 (3) 2021, 395-405

correlation between all independent variables is less than 0.70 . And the value of tolerance is more than o.10 while VIF is lower than 10. So there is no multicollinearity issue as can be seen in table 4.2

Table 4.2: Tolerance Value and the Variance Inflation Factor (VIF)

\begin{tabular}{|l|l|l|}
\hline & Collinearity Statistics \\
\hline Independent Variables & Tolerance & VIF \\
\hline Heuristic factors & 0.758 & 1.319 \\
\hline Herding & 0.931 & 1.074 \\
\hline Prospect factors & 0.766 & 1.306 \\
\hline Market factors & 0.815 & 1.228 \\
\hline
\end{tabular}

In this analysis, it has revealed that total variance explained is $64.795 \%$ which is in acceptable range and the retained variables are divided into seven factors (herding, market factors, heuristic factors, prospect factors, investment decision, investment performance and financial literacy), the value of $\mathrm{KMO}$ is 0.937 ( $\mathrm{sig}=0.000$ ), and 64.795 percent of the total variance explained, and all factor loads are higher than 0.5 . These indicators demonstrate that for these factors, the factor analysis is very sufficient and approved.

While performing CFA, it has been observed that the 7-factor model (containing heuristic factors, herding, prospect factors, market factors, investment decision, investment performance and financial literacy) fits well with the data (comparative fit index [CFI] $=0.95$, Tucker-Lewis index [TLI] $=0.95$, root mean square error of approximation $[$ RMSEA $]=0.04$ and (goodness of fit index $[\mathrm{GFI}]=$ o.85 significantly fit with the data much better than other factor. Therefore, these results indicated that the scale of all variables possessed adequate discriminant validity to test our hypotheses.

After completion of EFA and CFA, the reliability and validity analysis for each aspect is given below. The level of composite reliability shown in the table showing that a substantial percentage of the loadings of the products factor is also more prominent than 0.7 , these loadings appear in their respective sections acknowledging the internal consistency of the selected items. Convergent validity is declared in the existing examination by using an average variance extracted (AVE) for each element.They offered the limit to ensure the convergent validity more notable than and contrasting with 0.5 .

Table 43: Reliability and validity

\begin{tabular}{|l|l|l|l|l|l|}
\hline & $\begin{array}{l}\text { Composite } \\
\text { Reliability }\end{array}$ & $\begin{array}{l}\text { Cronbach' } \\
\text { Alpha }\end{array}$ & AVE & MSV & ASV \\
\hline Heuristic factors & 0.912 & 0.913 & 0.509 & 0.255 & 0.152 \\
\hline Herding & 0.932 & 0.931 & 0.774 & 0.205 & 0.075 \\
\hline Prospect factors & 0.909 & 0.910 & 0.589 & 0.231 & 0.134 \\
\hline Market factors & 0.917 & 0.918 & 0.648 & 0.305 & 0.154 \\
\hline Investment decision & 0.936 & 0.936 & 0.675 & 0.518 & 0.238 \\
\hline $\begin{array}{l}\text { Investment } \\
\text { performance }\end{array}$ & 0.900 & 0.902 & 0.750 & 0.348 & 0.249 \\
\hline Financial literacy & 0.943 & 0.943 & 0.674 & 0.518 & 0.156 \\
\hline
\end{tabular}




\section{Review of Economics and Development Studies, Vol. 7 (3) 2021, 395-405}

\subsection{Regression Results}

We utilize the Hayes (2013) process tool for moderated mediation approach. Analysis is completed in two stages: first, we used Process Model 4 to test mediation, using 5000 bootstrap samples with 95 percent bootstrap CI. We take into consideration the probability that the value of the hypothesized moderator could depend on a statistically significant indirect impact. The hypothesized moderator was presented in the second stage and the entire moderated mediation model was tested (in process Model 7).By creating an interaction term based on behavioral variables and financial literacy, the moderation test was carried out. These variables grand mean centered beforehand (Aiken \& West, 1991). Three different moderator levels evaluated the conditional indirect effect: mean value, as well as one standard deviation below and above. A basic moderation model was also used in the Hayes method tool (Model 1) in an attempt to further explore the nature of moderation across basic slopes.

Table 4.4: Regression results

\begin{tabular}{|c|c|c|c|c|c|c|}
\hline \multicolumn{2}{|l|}{ Moderated mediation } & $\mathrm{B}$ & SE & $\mathrm{t}$ & LLCI & ULCI \\
\hline \multicolumn{2}{|c|}{$\begin{array}{l}\text { DV: Investment decision (Mediator) } \\
\left(\mathrm{R}^{2}=0.55^{* *}\right)\end{array}$} & & & & & \\
\hline \multicolumn{2}{|l|}{ Constant } & & 0.25 & 6.03 & & \\
\hline \multicolumn{2}{|l|}{ Behavioral factors } & $0.55^{* * *}$ & 0.07 & 8.39 & 0.42 & 0.68 \\
\hline \multicolumn{2}{|l|}{ Financial literacy } & $0.24^{* * *}$ & 0.21 & 1.33 & -0.17 & 0.66 \\
\hline \multicolumn{2}{|c|}{ Behavioral factors $\times$ Financial literacy } & 0.105 & 0.06 & 1.82 & -0.008 & 0.218 \\
\hline \multicolumn{7}{|c|}{ DV: Investment performance $\left(\mathrm{R}^{2}=0.47^{* * *}\right)$} \\
\hline \multicolumn{2}{|l|}{ Constant } & & 0.25 & -3.22 & & \\
\hline \multicolumn{2}{|l|}{ Investment decision } & $0.31^{* * *}$ & 0.05 & 6.40 & 0.21 & 0.40 \\
\hline \multicolumn{2}{|l|}{ Behavioral factors } & $0.85^{* * *}$ & 0.07 & 11.02 & 0.71 & 1.01 \\
\hline Indirect Effect & Effect & \multicolumn{2}{|l|}{ Boot SE } & Boot LLCI & \multicolumn{2}{|c|}{ Boot ULCI } \\
\hline BF-IP via ID & 0.25 & \multicolumn{2}{|l|}{0.06} & 0.14 & \multicolumn{2}{|c|}{0.39} \\
\hline Conditional indirect effect & Effect & \multicolumn{2}{|l|}{ Boot SE } & Boot LLCI & \multicolumn{2}{|c|}{ Boot ULCI } \\
\hline$-1 S D$ & 0.12 & \multicolumn{2}{|l|}{0.05} & 0.04 & \multicolumn{2}{|c|}{0.23} \\
\hline $\mathrm{M}$ & 0.19 & \multicolumn{2}{|l|}{0.05} & 0.09 & \multicolumn{2}{|c|}{0.31} \\
\hline$+1 \mathrm{SD}$ & 0.20 & \multicolumn{2}{|l|}{0.06} & 0.10 & \multicolumn{2}{|c|}{0.32} \\
\hline
\end{tabular}

The analysis demonstrate that there was a significant positive direct relationship between behavioral factors (heuristic factors, herding, prospect factors and market factors) and investment performance $(\beta=0.85, \mathrm{p}<0.001)$, thus support for Hypothesis 1. It is consistent with the findings of Keswani et al (2019). Behavioral factors (heuristic factors, herding, prospect factors and market factors) were also positively and significantly associated to investment decision $(\beta=0.55, \mathrm{p}<0.001)$, therefore supporting Hypothesis 2. Investment decision was positively and significantly related to investment performance $(\beta=0.31, \mathrm{p}<0.001)$. In addition, we saw a significant indirect effect of behavioral factors (heuristic factors, herding, prospect factors and market factors) on investment performance through Investment decision, $\beta=0.25,95 \% \mathrm{CI}(0.14,0.39)$, hence supporting Hypothesis 3.The analysis also showed that the interaction term created with behavioral factors (heuristic factors, herding, prospect factors and market factors) and financial literacy was insignificant ( $\beta=0.11, p=0.068$ ), that does not support Hypothesis 4. Behavioral factors (heuristic factors, herding, prospect factors and market factors) had a significant indirect effect on investment performance via investment decision when financial literacy was low, $\beta=0.12,95 \% \mathrm{CI}(0.04,0.23)$ and moderate, $\beta=0.19 ; 95 \% \mathrm{CI}(0.10,0.30)$, and high, $\beta=0.20 ; 95 \%$ CI $(0.10,0.32)$. 


\section{Review of Economics and Development Studies, Vol. 7 (3) 2021, 395-405}

We also test the effect of all behavioral factors (heuristic factors, herding, prospect factors and market factors) on the investment decision and performance to know about the impact of all these variables so that we can understand and conclude which behavioral factors have a major influence on investment decision and performance. We also test the moderating role of financial literacy on all these behavioral factors (heuristic factors, herding, prospect factors and market factors) separately and their

relation with the investment decision and performance and found the $\mathrm{R}^{2}$ from $35 \%$ to $51 \%$ in each case respectively.

\section{Conclusions, Implications and Limitations}

It is concluded from the result that behavioral factors (heuristic factors, herding, prospect factors and market factors) have a positive and significant effect on the investment decision and performance. It also reveals that investment decision has a significant positive effect on investment performance and also performs mediating role between behavioral factors (Heuristic factors, Herding, Prospect factors and Market factors) and investment performance.

It means in Pakistan Stock market people showing behavioral biases while making their investment decision. They rely on heuristic factors and investors use heuristic in uncertain situation while making their investment decision and showing overconfidence. It has observed that investors during their financials decisions follow the actions of majority in the market. Market factors also have a significant positive relation with investment decision and performance. Financial literacy also shows a significant positive relation with investment decision and performance. But financial literacy doesn't show any moderating role between behavioral factors and investment decisions. In addition to this, individual investors can ultimately take advantage from the results of this research along with security organizations as a guide for their analysis and forecasting of security market trends.

This research can be used for PSX investors to improve their investment efficiency because overconfidence neglects the prevailing risk in the market which can affect the investment performance. This study has consequences and significant impact for decision makers. Investors may be motivated by overconfidence and herd behavior to bear unnecessary hazards that occurs redundant market fluctuations. For investors, better reliability, readily usable information also increases their financial decision-making. Educating investors more about market as well as the risk of their investments becoming unconventional is critical. In the case, the Securities and Exchange Commission might recommend that qualitative and quantitative details be disclosed in its entirety in relation to the relevant uncertainties to which companies are susceptible.

The cross section design of the study indicates limitation as study is conducted in Pakistan Stock Exchange and cannot be generalized for rest of the world. Further, study recommended to investigate all investor types and in all financial markets including the behaviors of institutional investors. Along with behavioral financial factors, we should consider some economic factors that could have an impact on investor's decision.

\section{Reference}

Abreu, M. (2014). Individual investors " behavioral biases (No. 21182-1356).

Aharon, D.Y, (2020). Uncertainty, Fear and Herding Behavior: Evidencefrom Size-Ranked Portfolios, Journal of Behavioral Finance, DOI:10.1080/15427560.2020.1774887.

Ahmad, M. (2018). Impact of Neurotransmitters, Emotional Intelligence and Personality on Investor's

Behavior

and 


\section{Review of Economics and Development Studies, Vol. 7 (3) 2021, 395-405}

Investment Decisions, Pakistan Journal of Commerce and Social Sciences,12 (1), 330-362

Ahmed, Z., Ramakrishnan, S, and Noreen, A. (2018). “Two Sides of a Coin: Effects of Perceived and Actual Financial Literacy on Investment Decision Making Behavior Mediated by Financial Risk Tolerance, International Journal of Engineering \& Technology, 7 (4), 499 504 .

Aiken, L. S., \& West, S. G. (1991). Multiple regression: Testing and interpreting interactions. Newbury Park, CA: Sage.

Allgood, S. and Walstad, W.B. (2016), "The effects of perceived and actual financial literacy on financial behaviors", Economic Inquiry, 54(1), 675-697.

Al-Tamimi, H.A. and Kalli, A.B. (2009).Financial literacy and investment decisions of UAE investors. The Journal of Risk Finance, 10(5), 500-516.

Antony, A,. (2019). Behavioral finance and portfolio management: Review of theory and literature. DOI: $10.1002 /$ pa.1996

Areiqat, A.Y., Abu-Rumman,A., Al-Alani, Y.S. and Alhorani, A. (2019). Impact of behavioral finance on stock investment decisions applied study on a sample of investors at Amman Stock Exchange.Academy of Accounting and Financial Studies Journal, 23(2), 1-17.

Arif, K. (2015). Financial Literacy and other Factors Influencing Individuals' Investment Decision: Evidence from a Developing Economy (Pakistan). Journal of Poverty, Investment and Development, 12(1), 74-84.

Babajide, A.A. \&Adetiloye, K.A. (2012). Investors' Behavioral Biases and the Security Market: An Empirical Study of the Nigerian Security Market, Accounting and Finance Research, 1(1), 219-229.

Baker, H.K. \& Nofsinger, J. (2010). Behavioral Finance, Investors, Corporations and Markets. Kolb Series in Finance, Essential Perspectives. NJ: John Wiley \& Sons. Inc.

Carlson, J. P., Vincent, L. H., Hardesty, D. M. and Bearden, W. O. (2009).Objective and subjective knowledge relationships: A quantitative analysis of consumer research findings,"Journal of Consumer Research, 35(5), 864-876.

Cooper, D. R., \& Schindler, P. S. (2003). Business research methods (8th ed.). Boston: MA: McGraw Hill

Gouw, D. G. and Shuttleworth, C. (2009) Financial literacy: an interface between financial information and decision-makers in organisations, Southern African Business Review, 13(2), 141-165.

Hair, J., Black, W. C., Babin, B. J., \& Anderson, R. E. (2010). Multivariate data analysis (7th ed.). Upper saddle River, New Jersey: Pearson Education International.

Hayes, A. F. (2013). An introduction to mediation, moderation, and conditional process analysis: A regression-based approach. New York, NY: Guilford Press.

Hodge, V. J., \& Austin, J. (2004). A survey of outlier detection methodologies. Artificial Intelligence Review, 22(2), 85-126.

Jahanzeb, A., Muneer, S. and Rehman, S. (2012). Implication of Behavioral Finance in Investment Decision-making Process.Information Management and Business Review, 4(10), 532-536.

Javed, M. A., \& Marghoob, S. (2017). The effects of behavioural factors in investment decision making at Pakistan stock exchanges. Journal of Advanced Research in Business and Management Studies, 7(1), 104-106.

Jhandir, S.U \& Elahi, M.A. (2014).Behavioral Biases in Investment Decision Making and Moderating Role of Investor's Type.

Kahneman, D. \&Tversky, A. (1979). Prospect theory: An analysis of decision making under risk. Econometrica, 47(2), 263-291.

Kanagasabai, B, and Aggarwal, B. (2020), The Mediating Role of Risk Tolerance in the 


\section{Review of Economics and Development Studies, Vol. 7 (3) 2021, 395-405}

Relationship between Financial Literacy and Investment Performance, International Journal of Theory \& Practice, 11(1), 83-114.

Keswani, S., Dhingra, V. and Wadhwa, B. (2019). Impact of behavioral factors in making investment decisions and performance: study on investors of National Stock Exchange. International Journal of Economics and Finance, 11(8), 80-90.

Khan, H. H., Naz, I., Qureshi, F., \& Ghafoor, A. (2017). Heuristics and stock buying decision: Evidence from Malaysian and Pakistani stock markets. Borsa Istanbul Review, 17(2), 106109.

Kyle, A. and Wang, F. (1997). Speculation Duopoly with Agreement to Disagree: Can Overconfidence Survive the Market Test? Journal of Finance, 52 (5), 2073-2090.

Lusardi, Annamaria and Olivia Mitchell (2014). “The Economic Importance of Financial Literacy: Theory and Evidence," Journal of Economic Literature, 52(1), 5-44.

Mahmood, Z. Kouser, R. Abbas, S, S and Saba, A. (2016). "The Effect of Hueristics, Prospect and Herding Factors on Investment Performance”. Pakistan Journal of Social Sciences (PJSS), 36(1), 475-484.

Mittle, S.K, (2019), Behavior biases and investment decision: theoretical and research framework, Qualitative Research in Financial Markets, DOI 10.1108/QRFM-09-2017-0085, 1755-4179

Nayak, R., Kumar, D. Y. (2020). Impact of Heuristic Bias and Prospect Bias on Share Market Investment Decision Making.UGC care Journal, Vol. 40 (26), 2394-3114

Ngoc, L. T. (2014). Behavior Pattern of Individual Investors in Stock Market. International Journal of Business and Management, 9(1), 3-5.

Parveen, S., Satti, Z.W., Subhan, Q.A and Jamil, S. (2020), Exploring market overreaction, investors'sentiments and investmentdecisions in an emerging stock market, Borsa_Istanbul Review 20-3 224-235

Pasewark, W. R., \& Riley, M. E. (2010). It's a matter of principle: the role of personal values in investment decisions. Journal of Business Ethics, 93(2), 237-253.

Peters, E.E. (1996) Chaos and Order in the Capital Markets, 2nd ed., John Wiley and Sons Inc., New York.

Phuoc, L., \& Thi Thu Ha, D. (2011). Behavioral factors influencing individual investors' decisionmaking and performance.: A survey at the Ho Chi Minh Stock Exchange. Thesis of Master in the University of Umeå University, Sweden.

Quershi, S. A., \& Hunjra, I. A. (2012). Factors affecting investment decision making of equity fund managers. Wulfenia Journal, 19(10), 280-291.

Shiller, R. J. (2000). Irrational exuberance. Princeton: Princeton University Press.

Slovic, P., Fischhoff, B and Lichtenstein, S. (1977). "Behavioral Decision Theory", Annual Review of Psychology ,28: 1-39.

Tabachnick, G. B., \&Fidell, S. L. (2007).Using Multivariate Statistics (5th ed.). New York: Pearson Educational Inc.

Thaler, R. (1980), Toward a positive theory of consumer choice, Journal of Economic Behavior \& Organization, 1(1), 39-6o.

Abdin, S. Z., Farooq, O., Sultana, N., \& Farooq, M. (2017). The impact of heuristics on investment decision and performance: Exploring multiple mediation mechanisms. Research in International Business and Finance, 42, 674-688.

Waweru, N., M., Munyoki, E., \&Uliana, E. (2008). The effects of behavioral factors in investment decision-making: a survey of institutional investors operating at the Nairobi Stock Exchange. International Journal of Business and Emerging Markets, 1(1), 24-41.

Zahera, S, A and Bansal, R. (2018). Do investors exhibit behavioral biases in investment decision making? A systematic review. Qualitative Research in Financial Markets, 10(2), 210-251. 